\title{
Unboxing the black box-one step forward to understand the soil microbiome: A systematic review
}

\author{
Apurva Mishra ${ }^{1,2} \cdot$ Lal Singh $^{2} \cdot$ Dharmesh Singh $^{3}$ D
}

Received: 3 November 2021 / Accepted: 10 January 2022 / Published online: 2 February 2022

(c) The Author(s) 2022

\begin{abstract}
Soil is one of the most important assets of the planet Earth, responsible for maintaining the biodiversity and managing the ecosystem services for both managed and natural ecosystems. It encompasses large proportion of microscopic biodiversity, including prokaryotes and the microscopic eukaryotes. Soil microbiome is critical in managing the soil functions, but their activities have diminutive recognition in few systems like desert land and forest ecosystems. Soil microbiome is highly dependent on abiotic and biotic factors like $\mathrm{pH}$, carbon content, soil structure, texture, and vegetation, but it can notably vary with ecosystems and the respective inhabitants. Thus, unboxing this black box is essential to comprehend the basic components adding to the soil systems and supported ecosystem services. Recent advancements in the field of molecular microbial ecology have delivered commanding tools to examine this genetic trove of soil biodiversity. Objective of this review is to provide a critical evaluation of the work on the soil microbiome, especially since the advent of the NGS techniques. The review also focuses on advances in our understanding of soil communities, their interactions, and functional capabilities along with understanding their role in maneuvering the biogeochemical cycle while underlining and tapping the unprecedented metagenomics data to infer the ecological attributes of yet undiscovered soil microbiome. This review focuses key research directions that could shape the future of basic and applied research into the soil microbiome. This review has led us to understand that it is difficult to generalize that soil microbiome plays a substantiated role in shaping the soil networks and it is indeed a vital resource for sustaining the ecosystem functioning. Exploring soil microbiome will help in unlocking their roles in various soil network. It could be resourceful in exploring and forecasting its impacts on soil systems and for dealing with alleviating problems like rapid climate change.
\end{abstract}

Keywords Soil microbiome $\cdot$ Nutrient cycling $\cdot$ Soil biodiversity $\cdot$ Soil networks $\cdot$ Climate change

\section{Introduction}

Soil is the most substantial pool of biological diversity and organic matter on terrestrial land that reinforces a huge range of processes important for life sustenance on Earth $[28,102]$. It is still conceivably the least comprehended

Dharmesh Singh

singhdharmesh24@gmail.com

1 Academy of Scientific and Innovative Research [AcSIR], Ghaziabad 201002, India

2 Environmental Biotechnology and Genomics Division, , CSIR-National Environmental Engineering Research Institute, Nehru Marg, Nagpur 440020, Maharashtra, India

3 Institute for Medical Microbiology, Immunology and Hygiene, Technical University of Munich, Trogerstrasse 30, 81675 Munich, Bavaria, Germany and acknowledged of Earth's environment. Soil accounts for denser biodiversity per unit territory than observed anywhere aboveground and it is a hub for biological and molecular interactions [6, 139]. With their subterranean networks, soil is firmly connected to aboveground networks through multi-trophic communications, nutrient cycling, and plant-soil feedback. It is also responsible for administering the functioning of ecosystems and working toward ecosystem services [7, 36]. Soil microscopic biomass matches or even in some cases exceeds the aboveground biomass, with soil frequently containing greater than a thousand kilograms of microscopic biomass carbon per hectare [9, 25]. The scientific world and the common man are more concerned about the macroscopic environment, and much lesser is known about the microscopic biota that is hidden in the heterogeneous soil, although these organisms along with plants, rule the Earth's living biomass [9, 46]. 
Understanding the composition of soil microscopic biota and their functional role is increasing gradually with the advancement in sequencing techniques [46]. With this progressive understanding of soil microscopic biodiversity, it is required to investigate a variety of soil functions supported by an unknown catalogue of organisms that have a strong involvement in soil functions, along with other ecosystem services $[13,122]$. The soil microbiome is also involved in climate change processes and regulation of greenhouse gas emissions $[46,100]$. The recent soil microbiome insights with huge prospects are anticipated from all fields of life.

To decipher the current state of knowledge available for soil microbiome and understanding the trend in soil microbiome study, we performed a systematic literature search using the Clarivate Web of Science Core Collection on 22.7.2021 following with combination of keywords as—*soil* AND microbiom* OR *soil* AND biota* OR *soil* AND *biodiversit* ranging from a period of 2005 to 2021. This time period was chosen due to introduction of sequencing-by-synthesis technology was introduced by 454 Life Sciences in 2005, [90]. This technology eventually revolutionized the field of soil microbiome in years to follow and continues to do so. To narrow it down, document types under book chapters, editorial managements, reviews, books, news items, book reviews, reprints, retracted publications, biographical items, and retractions were removed from the searched results, yielding 21,745 studies. This list was further screened manually to remove ones focusing only on culturable microbial diversity or the ones studying only soil macro-invertebrates or plants or unrelated topics etc. This led to a final list containing 7434 studies and now we could say with authority that the scientific community has started to take more and more interest into the subject of soil microbiome in the recent years Fig. 1.

The presence and role of soil microbiome remains understated in soil processes, which could be possibly due to the notion of it being ecologically redundant [36]. Many basic physiological and behavioral aspects of soil organisms; their interactive biotic relationships among themselves or with the above soil biota; their responses to the different abiotic and biotic factors; their spatial and temporal patterns and functional roles concerning soil niche—are regularly ignored or
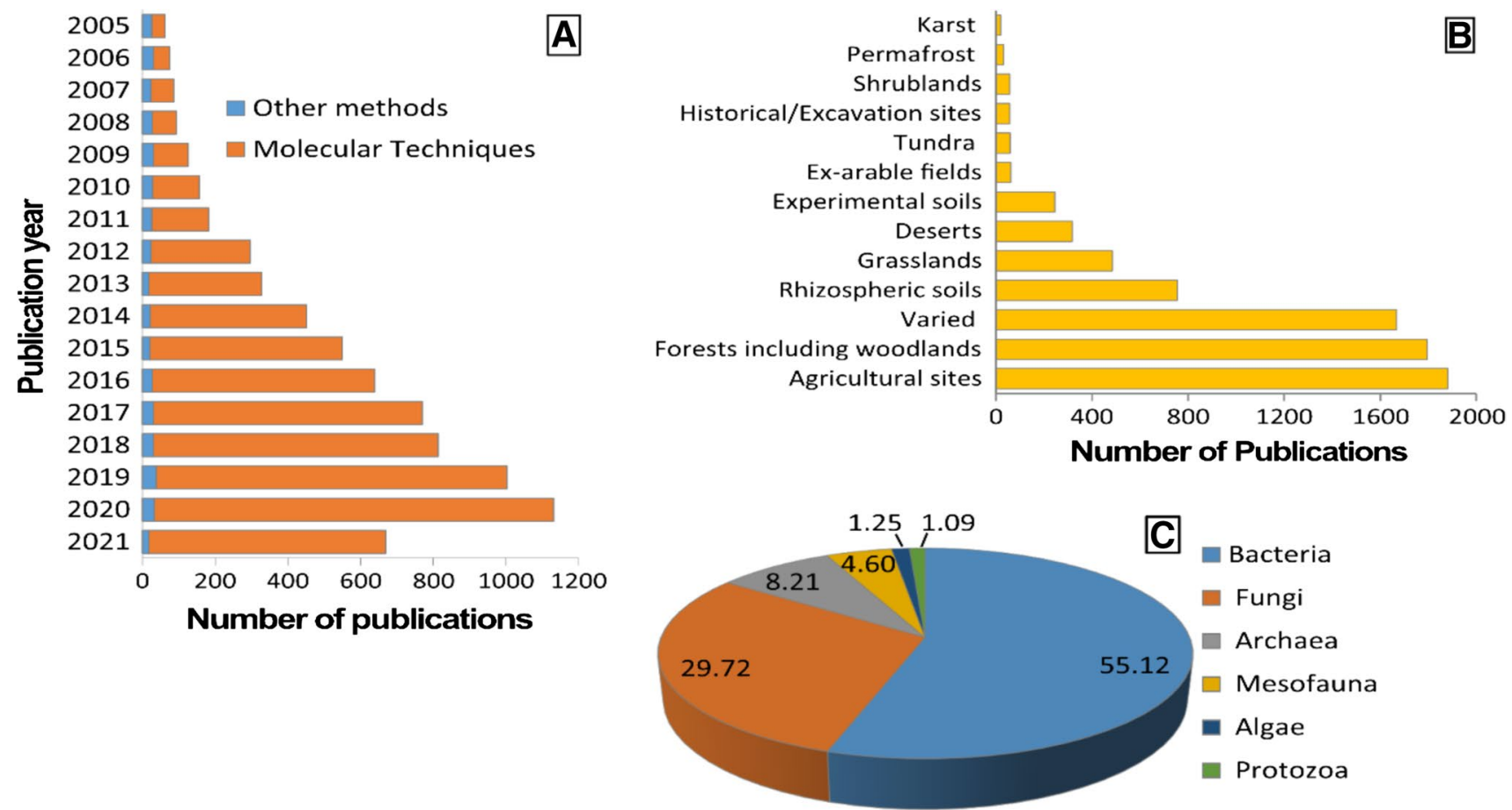

Fig. 1 Publication trend of scientific articles in the field of soil microbiome over time [A] Numbers of scientific articles published in the field of the soil microbiome since advent of next generation sequencing in 2005. Molecular techniques include FISH, qPCR, DGGE, RFLP, RAPD, amplicon-based next-generation sequencing, and shotgun metagenomics. Other methods include BIOLOG, PLFA, CLPP, FAME, and methods like Oostenbrick extraction, sugar flotation, Baermann funnel, and Tullgrens method followed by microscopy and enumeration [B] Number of scientific articles published under different terrestrial; natural or man-made ecosystems through- out the years. Agricultural sites include plantations, vineyards, orchards, arable lands, farmlands, and pastures; experimental soil including greenhouse or laboratory experiments, forensics soil samples, landfills, ore mines, etc.; rhizospheric soil include rhizosphere, rhizoplane and phyllosphere [most of the studies featuring rhizospheric soil also studied bulk soil]; deserts including arid or semiarid regions; grasslands including savannahs, meadows, etc.; varied includes publications studying more than two different sites in a single study. [C] Numbers of scientific articles published in the field of the soil microbiome distributed on the basis of the organism studied 
less explored as compared to the above ground biodiversity [46]. The aim of this review is to provide a critical evaluation of the work on the soil microbiome, especially since the advent of the NGS techniques. The novelty of this review lies in the systemic review of literature used above, wherein the details of tools used are explored over the period of time to discover the unexplored entity. The review also focuses on potential threats to soil microbiome. It also talks about the impact of climate change on the soil microbiome that is one of the urgent topic of the present times. This review is a sincere effort to combine the information about the current status of soil microscopic biome comprehensively and holistically, coupling soil assembly and biological processes with the current experimental and theoretical knowledge to improve predictive capacities. This improved understanding of soil biodiversity could be resourceful to supply plausible answers for the reported soil microbiome responses to environmental deviation like climate change. It is necessary to recognize and understand the functioning of this microscopic biome to build sustainable management of the soil and enrich the ecosystem along with its services.

\section{Factors affecting soil microbiome}

The richness and diversity of the soil microbiome are coordinated with the functioning of ecosystems and its composition within the soil environment relies on both chemical and physical properties of soil along with the anthropogenic factors that affect them [36]. The range of soil conditions affecting the organisms inhabiting are called edaphic factors, and they are part of abiotic factors.

The structure of the soil microbiome is affected largely by the edaphic properties and is the basic ecological filter [24]. Factors like soil structure influences the development of mesofauna, due to the high number of micropores in clay molecules, which in turn hampers the predatory activity of microorganisms. Similarly, distinctive types of soil biota have their very own inclinations for $\mathrm{pH}$ and it is observed that soil $\mathrm{pH}$ is significantly correlated with the development of a specific set of the soil microbiome. For instance, liming of acidic soil often results in shifts in the composition and abundance of soil microbiome including bacteria, fungi, archaea, nematodes, annelids, and microarthropods, as there is a significant increase in $\mathrm{pH}$ and nutrient concentrations [56]. With an increase in $\mathrm{pH}$, the soil bacterial-to-fungal ratio and nematode abundance increase as well [142]. Liming does not significantly influence the diversity of mites and collembolans, but a slight variation in the species composition speaks about the increase in dependent species and subsequently decreases in abundances [18]. Protists, on the other hand, which span the majority of microscopic eukaryotes, are only marginally influenced by $\mathrm{pH}$ [10].

Bacterial phyla such as Actinobacteria, Gemmatimonadetes, $\beta$ and $\delta$-Proteobacteria, Chloroflexi, and Nitrospirae strongly correlate with soil $\mathrm{pH}$ and favor distinct optimal $\mathrm{pH}$, which eventually shapes the microbial structure and diversity in soil along with the other factors as shown in Fig. 2 [7]. For bacteria, edaphic factors like soil $\mathrm{pH}$ and other soil nutrient concentrations strongly regulate its taxonomic diversity and composition due to the facilitation of nutrient accessibility in the soil, whereas in the case of fungi, climatic variables such as mean annual precipitation seem to have an upper hand over $\mathrm{pH}$ when explaining the diversity [7]. As change in climatic condition, like when $\mathrm{CO}_{2}$ is elevated enhances the abundance and activity of mycorrhizal fungi in relation to the production of spore-bearing structures, the fungal abundance increases.

The moisture content affects the microbiome as water availability is very important for maintaining the microbial
Fig. 2 Abiotic and biotic factors affecting soil bacterial and fungal communities. The scale here is based on a global study by Bahram et al., 2018 https://doi.org/10.1038/s41586018-0386-6 where they used metagenomics and metabarcoding to study topsoil samples [189 sites, 7,560 subsamples] for bacterial and fungal distribution and abundance on a latitudinal gradient. Abbreviations: MAT-mean annual temperature; MAP-mean annual precipitation; PET- potential evapotranspiration; NPP-net primary production

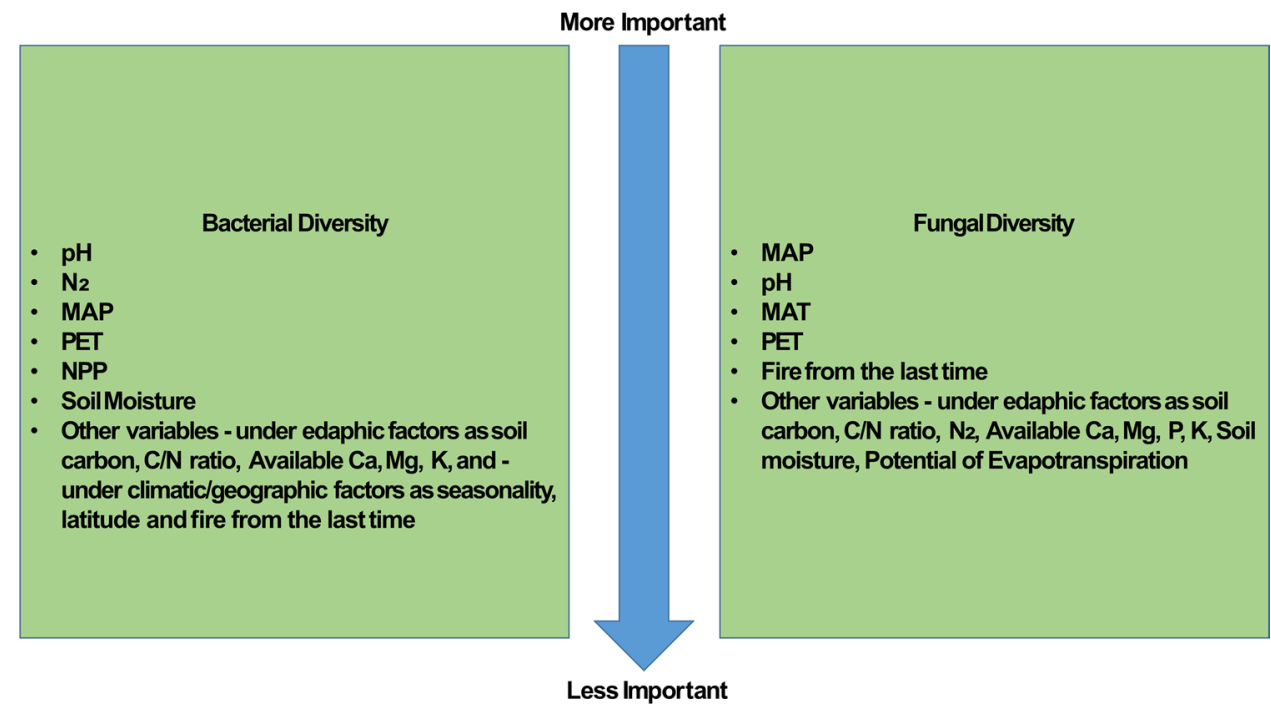


life and helps in their mobility in soil, dissolution of nutrients, and diffusion of gases [153]. Soil moisture was found to be influential in shaping the protistan community composition. Soil type and structure also affect the community composition of the soil microbiome with lighter soil structure favoring the growth of bacteria [41, 128]. Soil with clay molecules and a large number of micropores are found to limit the growth of mesofauna, which protect the microbes from predation [94]. Soil nutrient concentration such as carbon content and $\mathrm{C} / \mathrm{N}$ ratio plays a pivotal role in managing the diversity and structure of the soil microbiome $[114,157]$.

\section{The functional role of soil microbiome}

Soil microbiome plays a varied role in the terrestrial environments and understanding these can assist us in predicting the range of impacts, they may have on both natural and managed ecosystems Table 1. Soil microbiome is answerable for the mineralization of organic matter and nutrient discharge $[61,139]$ with groups like protozoans and nematodes assuming an essential job in the predation of soil microflora. These expand microbial respiration and stimulate nutrient mineralization like phosphorus [68]. The litter decomposition rate is chiefly directed by climatic conditions, i.e.,

Table 1 Functions performed by soil microbiome

\begin{tabular}{|c|c|c|c|c|}
\hline Organisms & $\begin{array}{l}\text { Functional } \\
\text { Group }\end{array}$ & $\begin{array}{l}\text { Representative } \\
\text { Member/s }\end{array}$ & Major Functions & References \\
\hline Mesofauna & Soil invertebrates & Collembola, Enchytraeids & $\begin{array}{l}\text { Aboveground shredding of litter } \\
\text { Development of soil structure } \\
\text { Decomposition and carbon } \\
\text { cycling }\end{array}$ & {$[42,95]$} \\
\hline Mainly bacteria and fungi & Decomposers & $\begin{array}{c}\text { Mycorrhizal Fungi, } \\
\beta \text {-proteobacteria }\end{array}$ & $\begin{array}{l}\text { Retain nutrients in their biomes } \\
\text { Synthesis of SOM } \\
\text { Decomposition of SOM } \\
\text { Carbon sequestration } \\
\text { Emissions of } \mathrm{CO}_{2} \text { and } \mathrm{CH}_{4} \\
\text { Enhance plant growth } \\
\text { Promote disease }\end{array}$ & {$[50,55,63,66,100]$} \\
\hline $\begin{array}{l}\text { Heterotrophic and auto- } \\
\text { trophic bacteria, fungi }\end{array}$ & Nutrients transformers & $\begin{array}{l}\text { Nitrosomonas, Pseudomonas, } \\
\text { Endophytes } \\
\text { Cyanobacteria }\end{array}$ & $\begin{array}{l}\text { Nitrification and denitrification } \\
\text { Phosphorous solubilization } \\
\text { Nutrient cycling } \\
\text { Add organic matter to soil } \\
\text { Nitrogen fixation } \\
\text { Soil stabilizers } \\
\text { Microbial residues stabilizer } \\
\text { Breakdown of nutrients }\end{array}$ & {$[29,82,111,145]$} \\
\hline Nitrogen-fixing bacteria & Nitrogen fixers & Rhizobium & $\begin{array}{l}\text { Converting atmospheric } \mathrm{N} \text { to } \\
\text { amides and ammonium ions } \\
\text { Nitrogen fixation }\end{array}$ & [84] \\
\hline Meiofauna & Biological Indicators & Nematodes, Protozoans & $\begin{array}{l}\text { Decomposition of organic matter } \\
\text { Nutrient cycling } \\
\text { Soil quality } \\
\text { Stimulate and control the activity } \\
\text { of bacterial populations } \\
\text { Control many disease-causing } \\
\text { pests }\end{array}$ & {$[83,107]$} \\
\hline \multirow[t]{2}{*}{ Microscopic Eukaryotes } & Bio-indicators & Protists & $\begin{array}{l}\text { Energy transfer } \\
\text { Key job as being consumer feed- } \\
\text { ing bacteria, fungi and other } \\
\text { small eukaryotes in food web } \\
\text { Improving soil quality }\end{array}$ & {$[10,45]$} \\
\hline & Soil Mineralization & Protozoa & $\begin{array}{l}\text { Regulate bacterial populations } \\
\text { Release plant available nitrogen } \\
\text { and other nutrients when feed- } \\
\text { ing on bacteria }\end{array}$ & [59] \\
\hline Archaea & $\begin{array}{l}\text { Soil nitrifiers } \\
\text { Nutrient Transformers }\end{array}$ & $\begin{array}{l}\text { Ammonia oxidizing archaea } \\
\text { Crenarchaeota }\end{array}$ & $\begin{array}{l}\text { Soil nitrification } \\
\text { Ammonia oxidation } \\
\text { Carbon and nitrogen turnover } \\
\text { Nitrification process }\end{array}$ & {$[59,151]$} \\
\hline
\end{tabular}


temperature and precipitation, at large spatial scales, while at a minor spatial scale, nutrient contents are more important [93]. However, eventually, soil organic matter [SOM] and litter disintegration are ruled by biotic activities [72]. There are numerous functional jobs that soil microbiome performs while balancing the ecosystem as described in Table 1 and sub-sections below.

\section{Role of the soil microbiome in managing SOM and C sequestration}

Soil microbiome with plant diversity is a huge participant in carbon storage and sequestration; they serve plentiful roles in the pedosphere, critical for the formation and turnover of SOM [130] to fulfil their needs of nutrient and energy for their growth and maintenance [81]. The prime way that C is stored in soil is in the form of soil organic matter [SOM] with around $80 \%$ of $\mathrm{C}$ in stable fractions of SOM is constituted of microbial residues and exudates [132, 147]. It shows that soil microbial biomass [SMB] holds a binary role in SOM turnover, balancing SOM mineralization and stabilization. A diverse range of organisms underwrite significantly to the living microbial mass of SOM [98], and the rate of degradation of organic matter is controlled by the microbiome and the abiotic factors like soil $\mathrm{pH}$ and temperature and in turn controls the microbial activity [149]. SOC storage is also affected by soil microbiome, influencing the soil structures, e.g., the burrowing activity of earthworms and enchytraeids is changed due to soil macro-porosity [33, $62,116]$. Other than earthworms, millipedes [136, 148], soil meiofauna such as mites, springtails, and enchytraeids are found to protect the $\mathrm{OM}$ from soil aggregation via fecal pellets which hold a huge amount of $\mathrm{C}$ in soil ecosystems [134, 135]. Predation by protists leads to a decline in the total bacterial biomass [30], an increase in the nutrient turnover, and overall stimulation of the soil microbiome [43]. Prokaryotic components of the microbiome like archaea carry out the two essential metabolisms for nutrient cycling globally, i.e., methanogenesis- and sulfate-dependent anaerobic methane oxidation [106]. In conclusion, the soil microbiome plays a huge role in the functioning of the ecosystem and performs different activities in partial fulfilment of it as discussed in Table 1 that mentions the representative taxa and the type of functions they perform.

\section{Role of the soil microbiome in nutrient cycling}

In the soil ecosystem, the nutrients are involved in a myriad of chemical and biochemical reactions, which are largely mediated by the soil microbiome. Soil microorganisms are acknowledged to support a plethora of functions related to carbon [C] cycling [140]. The balance between respiration and photosynthesis is dominant in $\mathrm{C}$ cycles on terrestrial systems. The atmospheric $\mathrm{C}$ in form of $\mathrm{CO}_{2}$ is fixed in soil by photo and chemoautotrophic microbes through Calvin cycle with the key enzyme ribulose 1,5-bisphosphate carboxylase/oxygenase or RuBisCO, [154] Phototrophic microbes from $\alpha-\beta$ - and $\gamma$-Proteobacteria and Cyanobacteria actively fix atmospheric $\mathrm{C}$ from the soil using the Calvin Cycle [143]. Chemoautotrophic members from bacterial phyla such as $\alpha$ - Proteobacteria, Actinobacteria, and Chloroflexi have been actively seen to fix the atmospheric $\mathrm{CO}_{2}$ in atmospheres like grasslands under dark conditions $[143,151]$, whereas chemoautrophic methanogenic archaea, acetogenes [86], can fix the atmospheric $\mathrm{CO}_{2}$ with inputs of exogenous $\mathrm{H}_{2}$ in paddy fields. In the soil $\mathrm{C}$ cycle, the role of mycorrhizal fungi is also important ranging from obligate symbionts like [AMF] that can solitary obtain carbon from the host plant to facultative symbionts like the ectomycorrhizal fungi $[\mathrm{ECM}]$ that can also mineralize organic carbon. Soil microbiome indisputably impacts the $\mathrm{C}$ cycle due to acts like the decomposition of litter, wherein the surface area increases. This allows the microbes to colonize more [52], followed by gathering of organic matter and stimulation of microbial activities [52]. Another important biogeochemical cycle is nitrogen cycle, where bacteria, archaea, and fungi help in converting the organic nitrogen into ammonium form by attacking the decaying plants and animals, i.e., the first step in the nitrogen cycle termed as ammonification [109]. After ammonification, specialized group of bacteria, and archaea, take over the chemical processes, like ammoniaoxidizing bacteria $[\mathrm{AOB}]$ and ammonia-oxidizing archaea [AOA], runs the nitrification process, thereby converting ammonia to nitrites and nitrates. $\beta$ - and $\gamma$-Proteobacteria, Nitrospirae, and members of phylum Thaumarchaeota possess representative microbes involved in the process of nitrification [138]. On the contrary, few soil prokaryotes like diazotrophs have an enzyme called dinitrogenase, which converts soil inorganic and organic nitrogen into ammonia, followed by nitrite and nitrate [34].

Another major growth-limiting nutrient is phosphorus. Soil phosphorus is washed off to the environment via different means like runoff or leaching, resulting in agricultural issues mainly delay in crop maturity, the decline in seed quality, and low crop yield, due to insufficient soil $\mathrm{P}$, and this is due to mineralization by soil microbes like bacteria [67]. Soil microbes like bacteria, archaea, and fungi help in solubilization and mineralization of P. Protozoans, nematodes, and other mesofauna help in immobilization of this available $\mathrm{P}$ and convert them to organic form [121]. AMF is also efficient in $\mathrm{P}$ uptake from soil and delivering it to plants [15].

\section{Threats to soil microbiome and biodiversity}

As of now, soil and their biomes are being undermined by debasement brought about by global environmental 
and climatic changes. The condition is again worsened by anthropogenic activities including changes in land use, pollution, and the introduction of new invasive species in newer environments, with possibly far-reaching impacts on Earth's biological systems [27]. One of the biggest threats is human intervention. Since the inception of agriculture, humans have rehabilitated the plant's local diversity by clearing land and growing selected plant species [27]. Additionally, pollutants entering the soil as a result of activities like oil spills and mining are also influencing the soil microbiome and the enormous ecosystem functions, offered by the soil [152]. Additionally, this belowground diversity can also be heavily impacted by physical disturbances of soil like compaction, erosion, sealing, habitat fragmentation, and other activities.

In recent decades, worldwide climate change has globally modified precipitation and temperature systems, which is affecting soil biodiversity both directly and indirectly through their influence on plant diversity and primary productivity [150]. Attention to soil biodiversity and its utilitarian significance will empower the advancement of economical administration practices, for which we will need a better understanding of the possible threats to soil biodiversity. Listed below are a few possible threats to the soil biodiversity -

\section{Invasion of alien or exotic species}

In natural ecosystems, different species have evolved together in such a way that usually no single species can overpower the system and hence they coexist. Then, there are invasive species, which are well known to pose risk to species diversity globally, and can be one of the reasons responsible for endemic biodiversity losses [118]. Biological invasion by alien species can have a remarkable impact on soil biodiversity and are of two types- invasive plants and invasion of the soil microbiome. Recent examinations have suggested that invasion by alien plants generally modifies the soil microbiome [155]. Although the effects vary with individual invasive plants and can have their distinct effect on the soil chemistry and structure, there could be cases where an invasive plant species with comparatively higher root biomass than local plants can release more nutrients and organic carbon to the surrounding rhizosphere. This eventually provides a stage for local soil microbes to flourish and can initiate positive feedback that promotes the invasive species. To cite one example, Prosopis juliflora, the Latin American tree which is tolerant to high temperatures and salinity stress, invaded semi-arid locations of Africa producing organic substances that are found to be toxic to the native plants due to allelopathic effects $[69,89]$. To add upon, it can host native nitrogen-fixing bacteria, like Rhizobium and Bradyrhizobium bacteria once the conditions further improved. Another example of plant invasion is by the weed Conyza canadensis, which had contrasting effects on different groups of soil fungi. A decrease in abundance of Ascomycota and Chytridomycota was observed in conjunction with an increase in the numbers of phylum Glomeromycota [155] at different degrees of invasiveness by the weed. Invasive plants also considerably influence the catabolic diversity of the soil microbes via their effect on the soil enzymatic activities, which illustrates the connection between litter decomposition, availability of nutrients, and rhizospheric microbial activity $[31,73]$ but each invasive plant species will have their own idiosyncratic effects on the soil microbiome not reproducible by other aliens [47].

Organisms like ants and soil-dwelling flatworms, or fungal pathogens can also invade the soil microbiome. The intrusion of outsider's microbiome in the new environment can meticulously affect their hosts and beneficiary ecosystems $[48,120]$. Invasion of soil microbiome particularly with ecosystem engineers like earthworms can have a dramatic impact on the recipient ecosystems. They can lead to a significant decline in native soil invertebrate diversity like in collembolans and oribatid mites, significant decline in mycorrhizal fungal colonization as well as homogenization of the microbial communities across the soil layers by bioturbation which was observed [35].

The biological systems generally inclined to serious effects of invasive species are those that have been separated geographically for an exceptionally prolonged period. For example, islands, because their local species can be highly different from the exotic species. One such example is invasions of rats on off-shore islands in New Zealand, which lead to extensive and cascading effects on island soil saprophytic communities accompanied by significant decrease in populations of enchytraeids, bacterivore nematodes, rotifers, and collembolans [40]. Such results exhibit that alien species as predators can indirectly induce strong shifts in soil microbiome through disruption in several trophic levels and local interaction pathways in soil.

\section{Pollution}

Soil is a tremendously complex environment that provides food, water, shelter, and air to the organisms inhabiting. Due to this property, pollutants that end up in the soil can have immediate effects on soil biodiversity [44]. Soil pollutants that are commonly seen are pesticides, heavy metals, high salt concentrations, oils, and fertilizers. Pollutants at a large range can end up in soil via varied routes like atmospheric fall, through waste disposal, industrial activities, accidental oil spills, and can have a far-reaching impact on the soil functioning.

Widespread pollutants as heavy metals [metal with a density $\geq$ of $5 \mathrm{~g} \mathrm{~cm}^{-3}$ ] are linked to toxicity and pollution. Heavy metals like copper, iron, and zinc are important for 
the physiological functioning of microbes to a given limit or else they become toxic, when present in high concentrations and their contamination leads to a decline in microbial biomass while enriching the heavy metal resistant microbial populations [97]. Amongst these, copper is reported to be one of the most common soil contaminants that can alter the community structure of many organisms like bacteria, archaea, and fungi [20] as it affects the various cellular enzymes and the proteins that are involved in the energy metabolism [144].

Agrochemicals like herbicides, insecticides, and chemical fertilizers are often used prudently, but still found to adversely affect the soil microbiome [92]. These chemicals are often applied to the field directly or sprayed on the soil strata and are hazardous for the non-targeted soil-borne organisms, which are assumed beneficial or commensal $[103,110]$. Over $95 \%$ of the applied herbicides and $98 \%$ of insecticides influence the non-targeted soil organisms and soil, which unfavorably affects the soil microcosms involving, soil microscopic fauna in field networks and soil biological system [58, 60, 85]. Correspondingly, a few investigations have stated that various pesticides quell soil enzymatic activities, which ultimately influence the nutrient status of soil.

\section{Acid rain and overloading of nutrients}

Acid rain is a mixture of both wet and dry material deposition from the atmosphere containing a higher amount of sulfuric and nitric acids. It mainly works by increasing soil acidity, affecting the microbes like bacteria and fungi, which further disrupt the organic matter transformed into nutrient forms. Among mesofauna, Collembolans and mites are sensitive to high acidity [146], while others such as enchytraeids are more resilient to high acidity. Communities of earthworms especially like Eisenia fetida are also affected by the soil acidification because earthworm do not survive at very acidic $\mathrm{pH}$; instead, they need a continuous calcium supply. The change in $\mathrm{pH}$ is inversely proportional to the concentration of ionized calcium [75]. By directly decreasing the soil $\mathrm{pH}$, acid rain helps in increasing the count of acid-tolerant soil fauna and vice versa. This in totality alters the soil microbiome [146] in conjunction with an increase in the soil bulk density thereby decreasing the movability and availability of $\mathrm{H}_{2} \mathrm{O} / \mathrm{O}_{2}$, which further modifies the soil microbiome and affects the soil's ecological function and processes. Acid rain also has negative effects on the plants, e.g., by increasing the soil acidity, aluminum is allowed to get solubilized and its free organic form which is toxic to the plant roots, which subsequently locks up phosphate and meanwhile starts reducing the concentrations of the essential plant nutrients. However, it is seen that in such case, ectomycorrhizal fungal species present on the root surfaces of some trees help them with the supply of soluble calcium to the soil that are subjected to acid rains [108].

Soil globally receive nutrients in different ways, either through natural processes or human activities, although human activities produced a large number of nutrients, e.g., $\mathrm{P}$ and $\mathrm{N}_{2}$ inputs are exceptionally high via agricultural lands due to the application of fertilizers. A significant plant community shift is observed over time in non-agricultural soil due to the excessive addition of nutrients. Nutrient flooding leads to change in the soil $\mathrm{pH}$ and shifts the carbon dynamics belowground due to changes in amounts and types of organic carbon, derived from plants and litter that are mineralized to carbon dioxides via microbial activities [108]. When soil are $\mathrm{N}_{2}$ or $\mathrm{P}$ amended or overloaded, the abundance of mycorrhizal fungal taxa usually declines and the growth of cyanobacterial taxa is inhibited [108]. One of the direct impacts of nutrient overloading on soil microbiome includes a reduction in the relative abundance of nitrogen-fixing bacteria and an increase in the taxa responsible for denitrification or nitrification process [108]. In general, addition of nutrients tends to encourage the taxa that have high demands for $\mathrm{N}_{2}$ and $\mathrm{P}$ and shift bacterial and fungal communities due to these cascading effects, thereby affecting the soil food web. This elevated nutrient soil profile is also known to impact the soil $\mathrm{C}$ cycle as it is generally observed that the decomposition of organic matter via microbes is lowered down when nitrogen is used as an amendment in soil. This is accompanied with a decline in the size of soil microbial biomass; however, the responses differ throughout different sites.

Given the myriad connections among plants and subterranean biota, one of the essential mechanisms through which nutrient alterations impact soil microbiome is by changing plant production and plant network types [113]. For instance, the addition of nutrients often supports the growth of weedy plants, which is one of the producers of high-quality litter, inhibiting the growth of microbial taxa that are specialized in the decomposition of recalcitrant litter affecting the soil micro and mesofauna in various ways.

\section{Intensive agriculture practices}

Effects of agriculture on soil microbiome are highly variable depending on the management system adopted. For instance, there are two types of agricultural systems-low input system or farming utilizes internal resources and tries to minimize the use of production inputs like purchased organic fertilizers and other is high input systems and utilizes huge equipment and commercial fertilizers, mostly for monoculture plantations using the conventional pattern often known as farming systems which utilize the synthetic fertilizers [11, 78]. A significant reduction in soil community diversity is generally observed in highly managed systems, while the diversity is mostly conserved in the lower input systems 
[37]. For example, the soil microfaunal, mesofaunal, and fungal community diversity is severely affected by the conversion of native forests to rubber monoculture plantations $[133,137]$. Monocultures as rubber, palm, or even maize are generally accompanied by a progressive increase in soil bulk density and suffer from soil compaction in the top layer of soil. This affects the microbial community, which in turn were to be predated upon by soil micro- and mesofauna like protists and nematodes. Physical disturbance in soil due to compaction reduces niche availability for several microarthropods, annelids, and others soil dwellers, and this might further reduce the soil microbiome abundances [79, 99]. Monocultures seem to favor fast-growing fungal phyla like Ascomycota, and slow-growing fungal groups belonging to Basidiomycota seem to be adversely affected by physiochemical changes in the monocultures. As with these high input systems, there is more soil disturbance, soil management practices dictate removal of leaf litter and roots, and regular application of fertilizers and pesticide might cause a perturbation of soil, negatively affecting slow growers like Basidiomycota [137]. Bacterial pathways are more favored in the high input systems ruled by the opportunistic bacterial feeding nematodes; on the contrary, low-input systems indulge fungal pathways dominated by the fungal feeding fauna-like termites. Protists are also negatively affected by the conversion of the rain forest to other plantations, whereas there is an increase in bacterial diversity $[12,124,127]$. Abundance of root-associated microbiota such as arbuscular mycorrhizal fungi $[\mathrm{AM}]$ as well as their network connectivity tends to be drastically affected by intense agricultural practices and is more preserved under low input systems such as organic farming [8].

A significant alteration in the soil, especially linked to soil structure, soil organic content, water-holding capacity, and porosity, causes soil tillage. The influence of tillage on the soil microbiome is highly variable, dependent on the soil characteristics and the type of tillage system [80]. There are three main tillage systems known- conventional tillage, i.e., plowing that breaks down the soil thereby destroying the soil structure and burying the crop residues, causing the most significant impact on soil-dwelling organisms [125]. The second type is the minimum tillage system, i.e., characterized by a reduction in tillage area and the last one is the no-tillage system, where the soil surface is relatively undisturbed and providing a comparatively stable habitat. It is seen that bacteria are more favored by conventional tillage systems, which in turn expect protists also to be favored as bacteria are their main source of food [156]. Collembolans are generally inhibited due to disturbances created by tillage depending on the type of environment and contrary mites showcase a wide range and more severe responses [16, 21, 70]. A study revealed that intensive agriculture is responsible for a reduction in soil biodiversity across Europe. In the study, four agricultural regions across Europe were examined for the effect of land-use intensity formulated based on structural diversity among the groups along with the body mass of the soil fauna. It was found that the species richness of collembolans, earthworms, and orbatid mites was affected negatively with increasing land-use intensity due to the significant effect of food web diversity [141].

\section{Climate change}

A long-term change in the average weather patterns or "climate change' can have long-term effects on the soil microbiome and biodiversity. Temperature, $\mathrm{CO}_{2}$ level, and soil moisture content can be altered by climate change, thereby influencing soil biodiversity [51]. Climate change impacts the networking between the soil microbiome, by influencing its stability with different ecosystems behaving differently to each stimulus [63]; for example, under soil warming, the soil microbial populations increase by $40-150 \%$ [63, 129].

There are various responses that soil microbiome uses to survive with the environmental conditions that are drastically changing, few of them are-

- Elevated $\mathrm{CO}_{2}\left[\mathrm{eCO}_{2}\right]$-Many studies have reported the microbiome shifts with $\mathrm{eCO}_{2}[63,77]$. A regional scale study in Australian grasslands showed that the microbial diversity [archaea, bacteria, and fungi] was significantly influenced by eCO2 over some time when exposed to [ambient $+550 \mathrm{ppm}]$ concentrations of atmospheric $\mathrm{CO} 2$ and higher temperatures [ambient $+2^{\circ} \mathrm{C}$ ] [53]. Changes in functions performed by soil microbiome under eCO2 could be analyzed through quantification of the gene abundances in the metagenomes particularly genes responsible for decomposition, nitrogen fixation [63]. It is also very essential to understand how vital environmental factors like temperature, nutrients, and precipitation interacts with $\mathrm{eCO}_{2}$ and this can help forecast the response of soil microbiome to $\mathrm{eCO}_{2}$.

- Increased temperature- Depending upon the biome, the response of high temperature varies on the soil microbiome. For example, warming effects on soil biodiversity show weaker responses in arid ecosystems, whereas in the Arctic regions the responses are quite prominent accompanied by a significant increase in the soil populations [131]. In grassland communities, a small increment in temperature has a clear impact on soil fauna participating in root growth [108]. Studies even revealed that warming has a striking influence on the soil fungal communities under different systems, causing either suppression or stimulation of fungal biomass and its activity considering the difference in vegetation and the soil moisture $[2,3,17,96]$. As for bacteria, members from Acidobacteria and Actinobacteria were found to be in 
higher proportions as compared to other bacterial phyla due to soil warming effects [123]. Although many models on climate predict that an increase in soil respiration and decrease in soil storage is found to have positive feedback as a result of warming, but is largely dependent on the ecosystems [39, 54].

- Permafrost thaw- Permafrost thaw of the Arctic soil is the most severe outcome of global warming. On Earth, around $20 \%$ of the terrestrial surface is occupied by permafrost soil, which is the vast reservoir of carbon that will represent the future allocation of carbon from the biosphere to the atmosphere [57]. The common feature of permafrost thaw is a change in soil moisture that largely manages the soil microbial activity [76]. Despite the indifferent conditions, permafrost is known to harbor a huge range of microbiota and especially prokaryotes and fungi with elevated functional diversity along with a huge number of unknown taxa [4, 38]. Few studies suggest that the response of microbial communities is significantly affected by the rise in temperature, which ultimately leads to change in ecosystem functioning [87]. Several metagenomic studies disclosed that the structure of the microbial community and functional capabilities in permafrost are different from those present in the active layer as compared to the permafrost microbiome that changes rapidly upon thawing [87, 104].

- Drought- In mesic grasslands, droughts are considered to be the main outcome of climate change [19]. The rising drought conditions are anticipating in the decreasing microbial functions, which are essential for the sustainability of ecosystems. Drought can endure high impacts on the soil microbiome in grassland ecosystems, due to the shift in vegetation to more drought-tolerant plant species and their consequent preference for various rootassociated microbes [32, 105]. Both bacterial and fungal networks respond differently to drought, in which bacterial networks were observed to be strongly impacted by drought over fungal networks, which may be due to their ability to tolerate a broad range of environmental conditions [26].

\section{Challenges and prospects in unboxing the black box of soil microbiome}

We have seen exceptional advances and insights into the understanding of the soil microbiome in the last decade, driven by improvements in the NGS technologies. This augmented understanding of soil microbiome research is accompanied by a wealth of data, which has led us to understand microbial communities like never before, including their interactions and effects in soil, with recent studies even trying to explore and predict these microbial networks at global scales $[49,88]$. Despite the great progress achieved in elucidating the taxonomical diversity, their application in soil ecology remains tough. First, many of the biogeochemical processes are not the product of a single metabolic pathway but the product of multiple interconnected pathways that can be carried out by a wide range of taxa [112]. Second, the large number of individual genes like $16 \mathrm{~S}$ and 18S rRNA and functional genes from dormant microscopic organisms may startle efforts to link functional processes to specific soil microbiome. Third, there are methodological concerns associated with linking specific taxa to particular metabolic processes; these consist of difficulties with accurate gene annotation [126], and the rapid turnover of transcripts, proteins, and metabolites [64]. Fourth, sequencing-based methodologies, which are extensively used to enumerate the abundances of taxa or functional genes in soil usually, offer mostly information about the relative abundances of taxa or genes and not their absolute abundances. Different taxa, genes, and their products are likely to be associated with different soil processes, and to examine this, different approaches are used to examine or to quantify the given set of gene responsible for that particular function [46]. And even if there is a direct relationship between the taxon and the process of interest, there is a need to understand the environmental constraints responsible for the taxa of interest. For instance, definite bacterial methane oxidizers can have different substrate affinities, in any event, when they become under controlled laboratory conditions [71].

In order to fine tune the understanding of this process, it is necessary to emphasize on each of these points result in much better understanding of the field and scope in future for numerous applications. It is attempted to narrow down approaches which could fine tune the efforts in exploring and understanding the soil microbiome efficiently.

As per the globally accepted standards for the soil microbiome field conceptualized in 2020 [5] by National Institute for Biological Standards and Control [NIBSC] for gut microbiome analysis by next-generation sequencing, this would potentially improve development of methods, reduce and check submissions of inaccurate findings, and allow for effective exchange of results among peers, globally. Furthermore, standards can open up inventions in the soil microbiome turf, as they disprove the obligation for everyone to use the same protocol as long as users corroborate their protocol with respect to the global standards [22].

Identification of interlinks between the diverse soil microbiome and their functional capabilities has always been difficult as only a small fraction of the soil-inhabiting taxa can be cultivated in the laboratories, where investigative experiments yielding detailed results can be obtained. This could be resolved by several methods like qPCR, amplicon sequencing, metagenomics, metabarcoding, and metatranscriptomics. Extensive efforts put into culturable isolation 
of soil microbes which are more responsive to cultivation especially from particular niches [91]. Genome sequencing and characterization of such isolates would be much easier and would provide much better insights in conjunction with the metagenomics data to answer pertinent ecological questions. Secondly, setting of simulated simplified microbiome experiments of much complex natural environments and studying them through the help of "OMICS" would yield insightful results and a better understanding of the problem. This could help us in manipulating the soil network to a lower level of complexity that is much easier to comprehend and might help us in observing the big picture [1]. This in conjunction with the metagenomic data of the original microbiome could help foresee the functional capacities of respective microbes and their role in the different bioprocesses and ultimately toward the ecosystem functioning $[115,117]$. Thirdly, development of functional annotation techniques instead of amplicon based sequencing which can only determine relative abundances of taxa or genes and not their absolute abundances without any knowledge of functional profiles in the studied environments [23].

Amplicon-based sequencing of marker genes [16S rDNA, $18 \mathrm{~S}$ rDNA, or ITS regions] have always been plagued by insufficient taxonomic resolutions due to inability of the present sequencing to sequence the whole gene. New longread sequencing technologies like PacBio circular consensus sequencing and loop genomics synthetic long-read sequencing technology [sFL16S] can sequence the entire marker gene such as 16S rRNA gene [14, 65]. These techniques could overcome the microbial misidentification caused by previous approach's inability to sequence the whole marker gene and could correctly classified to the sub-species clades $[14,65]$. These techniques could in turn generate high quality sequences from the unculturable environmental organisms, which can then help in developing robust databases including such environmental sequences. This would eventually reduce hitches where a huge extent of bacterial and archaeal taxa found in soil have taxonomic marker gene sequences that do not match to those found in reference databases [119].

\section{Conclusion}

There is no deficiency of information gaps that limit our comprehension of the soil microbiome and their respective roles in the soil environment. Indeed, even an answer to an inquiry as straightforward as 'what is the normal age time of soil microbes?' stays obscure. The nature, composition and complexity of soil microbiome and its interaction with other biotic and abiotic components are the key for future research applications. These applications include soil analytical studies for crop improvement, in agriculture and ecological studies for eco-restoration as well as geological studies for different types of land use pattern. There is no deficiency of information gaps that limit our comprehension of the soil microbiome and their respective roles in the soil environment. There are huge number of developing methodologies that can be and are being utilized to additionally investigate the phylogenetic and functional jobs of the soil biota. Harnessing this perspective of the soil biota and microbiome could possibly provide us with replies that can deliver us innovative solutions for present environmental challenges. Understanding the soil biodiversity at the level of taxonomic and functional attributes and its collective networking with the ecosystem functions is of utmost importance. For instance, to check the imbalances in soil and for monitoring soil quality, soil biodiversity should be considered as one of the key indicators. More efforts must be given toward developing management practices that will benefit soil biodiversity and resulting in improved restoration strategies. More specific, durable, and accurate technologies and methods are required to be developed for analyzing the soil microbiome and understanding the unknown facts about microbe-material interaction in soil.

Supplementary Information The online version contains supplementary material available at https://doi.org/10.1007/s00248-022-01962-5.

Acknowledgements The authors are grateful to CSIR-National Environmental Engineering Research Institute [CSIR-NEERI] for providing infrastructure facilities and acknowledge the Director, CSIR-NEERI. Ms. Apurva Mishra acknowledges the Academy of Scientific and Innovative Research [AcSIR], CSIR-HRDC and this work is a part of her Ph.D. thesis under AcSIR.

Funding Open Access funding enabled and organized by Projekt DEAL.

Declaration of competing interests The authors declare that they have no known competing financial interests or personal relationships that could have appeared to influence the work reported in this manuscript.

Open Access This article is licensed under a Creative Commons Attribution 4.0 International License, which permits use, sharing, adaptation, distribution and reproduction in any medium or format, as long as you give appropriate credit to the original author(s) and the source, provide a link to the Creative Commons licence, and indicate if changes were made. The images or other third party material in this article are included in the article's Creative Commons licence, unless indicated otherwise in a credit line to the material. If material is not included in the article's Creative Commons licence and your intended use is not permitted by statutory regulation or exceeds the permitted use, you will need to obtain permission directly from the copyright holder. To view a copy of this licence, visit http://creativecommons.org/licenses/by/4.0/. 


\section{References}

1. Aleklett K, Kiers ET, Ohlsson P, Shimizu TS, Caldas VE, Hammer EC (2018) Build your own soil: exploring microfluidics to create microbial habitat structures. ISME J 12(2):312-319

2. Allison SD, Treseder KK (2008) Warming and drying suppress microbial activity and carbon cycling in boreal forest soils. Glob Change Biol 14(12):2898-2909

3. Allison SD, McGuire KL, Treseder KK (2010) Resistance of microbial and soil properties to warming treatment seven years after boreal fire. Soil Biol Biochem 42(10):1872-1878

4. Altshuler, I., Goordial, J., \& Whyte, L. G. [2017]. Microbial life in permafrost Psychrophiles: from biodiversity to biotechnology [pp. 153-179]: Springer.

5. Amos GC, Logan A, Anwar S, Fritzsche M, Mate R, Bleazard T, Rijpkema S (2020) Developing standards for the microbiome field. Microbiome 8(1):1-13

6. Bach EM, Ramirez KS, Fraser TD, Wall DH (2020) Soil biodiversity integrates solutions for a sustainable future. Sustainability 12(7):2662

7. Bahram M, Hildebrand F, Forslund SK, Anderson JL, Soudzilovskaia NA, Bodegom PM, Harend H (2018) Structure and function of the global topsoil microbiome. Nature 560(7717):233-237

8. Banerjee S, Walder F, Büchi L, Meyer M, Held AY, Gattinger A, Van Der Heijden MG (2019) Agricultural intensification reduces microbial network complexity and the abundance of keystone taxa in roots. ISME J 13(7):1722-1736

9. Bar-On YM, Phillips R, Milo R (2018) The biomass distribution on Earth. Proc Natl Acad Sci 115(25):6506-6511

10. Bates ST, Clemente JC, Flores GE, Walters WA, Parfrey LW, Knight R, Fierer N (2013) Global biogeography of highly diverse protistan communities in soil. ISME $\mathbf{J}$ 7(3):652-659

11. Bossio DA, Scow KM, Gunapala N, Graham K (1998) Determinants of soil microbial communities: effects of agricultural management, season, and soil type on phospholipid fatty acid profiles. Microb Ecol 36(1):1-12

12. Brinkmann N, Schneider D, Sahner J, Ballauff J, Edy N, Barus H, Daniel R (2019) Intensive tropical land use massively shifts soil fungal communities. Sci Rep 9(1):1-11

13. Bünemann EK, Bongiorno G, Bai Z, Creamer RE, De Deyn G, de Goede R, Mäder P (2018) Soil quality-A critical review. Soil Biol Biochem 120:105-125

14. Callahan BJ, Wong J, Heiner C, Oh S, Theriot CM, Gulati AS, Dougherty MK (2019) High-throughput amplicon sequencing of the full-length 16S rRNA gene with single-nucleotide resolution. Nucleic Acids Res 47(18):e103-e103

15. Cavagnaro T, Barrios-Masias F, Jackson L (2012) Arbuscular mycorrhizas and their role in plant growth, nitrogen interception and soil gas efflux in an organic production system. Plant Soil 353(1-2):181-194

16. Chang L, Wu H, Wu D, Sun X (2013) Effect of tillage and farming management on Collembola in marsh soil. Appl Soil Ecol 64:112-117

17. Clemmensen KE, Finlay RD, Dahlberg A, Stenlid J, Wardle DA, Lindahl BD (2015) Carbon sequestration is related to mycorrhizal fungal community shifts during long-term succession in boreal forests. New Phytol 205(4):1525-1536

18. Cole L, Buckland S, Bardgett RD (2008) Influence of disturbance and nitrogen addition on plant and soil animal diversity in grassland. Soil Biol Biochem 40(2):505-514

19. Cook, B. I., Ault, T. R., \& Smerdon, J. E. [2015]. Unprecedented 21st century drought risk in the American Southwest and Central Plains. Science Advances, 1[1], e1400082.
20. Corcoll N, Yang J, Backhaus T, Zhang X, Eriksson KM (2019) Copper affects composition and functioning of microbial communities in marine biofilms at environmentally relevant concentrations. Front Microbiol 9:3248

21. Cortet J, Ronce D, Poinsot-Balaguer N, Beaufreton C, Chabert A, Viaux P, de Fonseca JPC (2002) Impacts of different agricultural practices on the biodiversity of microarthropod communities in arable crop systems. Eur J Soil Biol 38(3-4):239-244

22. Coxon, C. H., Longstaff, C., \& Burns, C. [2019]. Applying the science of measurement to biology: Why bother? PLoS biology, 17[6], e3000338.

23. Cullen CM, Aneja KK, Beyhan S, Cho CE, Woloszynek S, Convertino M, Rosen GL (2020) Emerging priorities for microbiome research. Front Microbiol 11:136

24. De Gannes V, Eudoxie G, Bekele I, Hickey WJ (2015) Relations of microbiome characteristics to edaphic properties of tropical soil from Trinidad. Front Microbiol 6:1045

25. De la Cruz-Amo L, Bañares-de-Dios G, Cala V, Granzow-de la Cerda Í, Espinosa CI, Ledo A, Cayuela L (2020) Trade-offs among aboveground, belowground, and soil organic carbon stocks along altitudinal gradients in Andean tropical montane forests. Front Plant Sci 11:106

26. De Vries FT, Griffiths RI, Bailey M, Craig H, Girlanda M, Gweon HS, Kretzschmar M (2018) Soil bacterial networks are less stable under drought than fungal networks. Nat Commun 9(1):3033

27. De Vries FT, Liiri ME, Bjørnlund L, Bowker MA, Christensen S, Setälä HM, Bardgett RD (2012) Land use alters the resistance and resilience of soil food webs to drought. Nat Clim Chang 2(4):276-280

28. Delgado-Baquerizo M, Maestre FT, Reich PB, Jeffries TC, Gaitan JJ, Encinar D, Singh BK (2016) Microbial diversity drives multifunctionality in terrestrial ecosystems. Nat Commun 7:10541

29. Dodds WK, Zeglin LH, Ramos RJ, Platt TG, Pandey A, Michaels T, Agusto FB (2020) Connections and feedback: aquatic, plant, and soil microbiomes in heterogeneous and changing environments. Bioscience 70(7):548-562

30. Ekelund F, Saj S, Vestergård M, Bertaux J, Mikola J (2009) The "soil microbial loop" is not always needed to explain protozoan stimulation of plants. Soil Biol Biochem 41(11):2336-2342

31. Elk, M. [2010]. A survey of plant root extracellular enzyme activity in native and invasive exotic plants of oak openings [Doctoral dissertation, University of Toledo].

32. Evans SE, Wallenstein MD (2014) Climate change alters ecological strategies of soil bacteria. Ecol Lett 17(2):155-164

33. Falco L, Coviella C (2016) Contribution of Amynthas gracilis [Megascolecidae] and Octolasion cyaneum [Lumbricidae] to soil physical stability: a mesocosm experiment. Revista de la Facultad de Ciencias Agrarias UNCuyo 48(1):115-127

34. Feng M, Adams JM, Fan K, Shi Y, Sun R, Wang D, Chu H (2018) Long-term fertilization influences community assembly processes of soil diazotrophs. Soil Biol Biochem 126:151-158

35. Ferlian O, Eisenhauer N, Aguirrebengoa M, Camara M, RamirezRojas I, Santos F, Thakur MP (2018) Invasive earthworms erode soil biodiversity: A meta-analysis. J Anim Ecol 87(1):162-172

36. Fierer N (2017) Embracing the unknown: disentangling the complexities of the soil microbiome. Nat Rev Microbiol 15(10):579

37. Franco AL, Sobral BW, Silva AL, Wall DH (2019) Amazonian deforestation and soil biodiversity. Conserv Biol 33(3):590-600

38. Frey, B., Rime, T., Phillips, M., Stierli, B., Hajdas, I., Widmer, F., \& Hartmann, M. [2016]. Microbial diversity in European alpine permafrost and active layers. FEMS microbiology ecology, 92[3], fiw018.

39. Friedlingstein P, Cox P, Betts R, Bopp L, von Bloh W, Brovkin V, Fung I (2006) Climate-carbon cycle feedback analysis: results from the C4MIP model intercomparison. J Clim 19(14):3337-3353 
40. Fukami T, Wardle DA, Bellingham PJ, Mulder CP, Towns DR, Yeates GW, Williamson WM (2006) Above-and below-ground impacts of introduced predators in seabird-dominated island ecosystems. Ecol Lett 9(12):1299-1307

41. Furtak K, Galazka A (2019) Edaphic factors and their influence on the microbiological biodiversity of the soil environment. Advancements of Microbiology 58(4):375-384

42. Gajda $€$, Gorgoń S, Urbisz AZ (2017) Food preferences of enchytraeids. Pedobiologia 63:19-36

43. Gao Z, Karlsson I, Geisen S, Kowalchuk G, Jousset A (2019) Protists: puppet masters of the rhizosphere microbiome. Trends Plant Sci 24(2):165-176

44. Gardi C, Jeffery S, Saltelli A (2013) An estimate of potential threats levels to soil biodiversity in EU. Glob Change Biol 19(5):1538-1548

45. Geisen S, Bonkowski M (2018) Methodological advances to study the diversity of soil protists and their functioning in soil food webs. Appl Soil Ecol 123:328-333

46. Geisen, S., Briones, M. J., Gan, H., Behan-Pelletier, V. M., Friman, V.-P., de Groot, G. A., . . Tiunov, A. V. [2019]. A methodological framework to embrace soil biodiversity. Soil Biology and Biochemistry, 136, 107536.

47. Gibbons SM, Lekberg Y, Mummey DL, Sangwan N, Ramsey PW, Gilbert JA (2017) Invasive plants rapidly reshape soil properties in a grassland ecosystem. MSystems 2(2):e00178-e216

48. Gladieux P, Feurtey A, Hood ME, Snirc A, Clavel J, Dutech C, Giraud T (2015) The population biology of fungal invasions. Mol Ecol 24(9):1969-1986

49. Guerra CA, Delgado-Baquerizo M, Duarte E, Marigliano O, Görgen C, Maestre FT, Eisenhauer N (2021) Global projections of the soil microbiome in the Anthropocene. Glob Ecol Biogeogr 30(5):987-999

50. Hale L, Feng W, Yin H, Guo X, Zhou X, Bracho R, Zhou J (2019) Tundra microbial community taxa and traits predict decomposition parameters of stable, old soil organic carbon. ISME J 13(12):2901-2915

51. Hamidov A, Helming K, Bellocchi G, Bojar W, Dalgaard T, Ghaley BB, Krzeminska D (2018) Impacts of climate change adaptation options on soil functions: A review of European casestudies. Land Degrad Dev 29(8):2378-2389

52. Hättenschwiler S, Tiunov AV, Scheu S (2005) Biodiversity and litter decomposition in terrestrial ecosystems. Annu Rev Ecol Evol Syst 36:191-218

53. Hayden HL, Mele PM, Bougoure DS, Allan CY, Norng S, Piceno YM, Williams AL (2012) Changes in the microbial community structure of bacteria, archaea and fungi in response to elevated $\mathrm{CO} 2$ and warming in an A ustralian native grassland soil. Environ Microbiol 14(12):3081-3096

54. Heimann M, Reichstein M (2008) Terrestrial ecosystem carbon dynamics and climate feedbacks. Nature 451(7176):289-292

55. Högberg, M. N., Skyllberg, U., Högberg, P., \& Knicker, H. [2020]. Does ectomycorrhiza have a universal key role in the formation of soil organic matter in boreal forests?. Soil Biology and Biochemistry, 140, 107635.

56. Holland J, Bennett A, Newton A, White P, McKenzie B, George T, Hayes R (2018) Liming impacts on soil, crops and biodiversity in the UK: a review. Sci Total Environ 610:316-332

57. Hultman J, Waldrop MP, Mackelprang R, David MM, McFarland J, Blazewicz SJ, Shah MB (2015) Multi-omics of permafrost, active layer and thermokarst bog soil microbiomes. Nature 521(7551):208-212

58. Imfeld G, Vuilleumier S (2012) Measuring the effects of pesticides on bacterial communities in soil: a critical review. Eur J Soil Biol 49:22-30
59. Islam, W., Noman, A., Naveed, H., Huang, Z., \& Chen, H. Y. [2020]. Role of environmental factors in shaping the soil microbiome. Environmental Science and Pollution Research, 1-23.

60. Jacobsen CS, Hjelms $\emptyset$ MH (2014) Agricultural soil, pesticides and microbial diversity. Curr Opin Biotechnol 27:15-20

61. Jacoby R, Peukert M, Succurro A, Koprivova A, Kopriva S (2017) The role of soil microorganisms in plant mineral nutrition-current knowledge and future directions. Front Plant Sci $8: 1617$

62. Jänsch S, Römbke J, Didden W (2005) The use of enchytraeids in ecological soil classification and assessment concepts. Ecotoxicol Environ Saf 62(2):266-277

63. Jansson, J. K., \& Hofmockel, K. S. [2019]. Soil microbiomes and climate change. Nature Reviews Microbiology, 1-12.

64. Jansson JK, Neufeld JD, Moran MA, Gilbert JA (2012) Omics for understanding microbial functional dynamics. Environ Microbiol 14(1):1-3

65. Jeong J, Yun K, Mun S, Chung WH, Choi SY, Lim MY, Han K (2021) The effect of taxonomic classification by full-length 16S rRNA sequencing with a synthetic long-read technology. Sci Rep 11(1): $1-12$

66. Johns, C. [2017]. Living soil : the role of microorganisms in soil health. Fut Direct Intl, 1-7.

67. Johnston, A. E., Poulton, P. R., Fixen, P. E., \& Curtin, D. [2014]. Phosphorus: its efficient use in agriculture Advances in agronomy [Vol. 123, pp. 177-228].

68. Johnston AS, Sibly RM (2018) The influence of soil communities on the temperature sensitivity of soil respiration. Nature ecology \& evolution 2(10):1597-1602

69. Kaur, R., Gonzales, W. L., Llambi, L. D., Soriano, P. J., Callaway, R. M., Rout, M. E., \& Gallaher, T. J. [2012]. Community impacts of Prosopis juliflora invasion: biogeographic and congeneric comparisons. PloS one, 7[9], e44966.

70. Kladivko EJ (2001) Tillage systems and soil ecology. Soil and Tillage Research 61(1-2):61-76

71. Knief C, Dunfield PF (2005) Response and adaptation of different methanotrophic bacteria to low methane mixing ratios. Environ Microbiol 7(9):1307-1317

72. Kooch, Y., Moghimian, N., Wirth, S., \& Noghre, N. [2020]. Effects of grazing management on leaf litter decomposition and soil microbial activities in northern Iranian rangeland. Geoderma, 361, 114100.

73. Kourtev PS, Ehrenfeld JG, Häggblom M (2002) Exotic plant species alter the microbial community structure and function in the soil. Ecology 83(11):3152-3166

74. Lal R, Monger C, Nave L, Smith P (2021) The role of soil in regulation of climate. Philos Trans R Soc B 376(1834):20210084

75. Lavelle P, Bignell D, Lepage M, Wolters V, Roger P-A, Ineson P, Dhillion S (1997) Soil function in a changing world: the role of invertebrate ecosystem engineers. Eur J Soil Biol 33(4):159-193

76. Lawrence, D. M., Koven, C. D., Swenson, S. C., Riley, W. J., \& Slater, A. [2015]. Permafrost thaw and resulting soil moisture changes regulate projected high-latitude $\mathrm{CO} 2$ and $\mathrm{CH} 4$ emissions. Environmental Research Letters, 10 [9], 094011.

77. Lee S-H, Kang H (2016) Elevated $\mathrm{CO} 2$ causes a change in microbial communities of rhizosphere and bulk soil of salt marsh system. Appl Soil Ecol 108:307-314

78. Lekberg Y, Koide R, Twomlow S (2008) Effect of agricultural management practices on arbuscular mycorrhizal fungal abundance in low-input cropping systems of southern Africa: a case study from Zimbabwe. Biology and Fertility of Soil 44(7):917-923

79. Li H, Ma Y, Liu W, Liu W (2012) Soil changes induced by rubber and tea plantation establishment: comparison with tropical rain 
forest soil in Xishuangbanna. SW China Environmental Management 50(5):837-848

80. Li, Y., Song, D., Liang, S., Dang, P., Qin, X., Liao, Y., \& Siddique, K. H. [2020]. Effect of no-tillage on soil bacterial and fungal community diversity: A meta-analysis. Soil and Tillage Research, 204, 104721.

81. Liang C, Schimel JP, Jastrow JD (2017) The importance of anabolism in microbial control over soil carbon storage. Nat Microbiol 2(8):1-6

82. Liang JL, Liu J, Jia P, Yang TT, Zeng QW, Zhang SC, Li JT (2020) Novel phosphate-solubilizing bacteria enhance soil phosphorus cycling following ecological restoration of land degraded by mining. ISME J 14(6): 1600-1613

83. Liu, T., Hu, F., \& Li, H. [2019]. Spatial ecology of soil nematodes: Perspectives from global to micro scales. Soil Biology and Biochemistry, 137, 107565.

84. Lladó S, López-Mondéjar R, Baldrian P (2017) Forest soil bacteria: diversity, involvement in ecosystem processes, and response to global change. Microbiol Mol Biol Rev 81(2):e00063-e116

85. Lo C-C (2010) Effect of pesticides on soil microbial community. J Environ Sci Health B 45(5):348-359

86. Lu Y, Conrad R (2005) In situ stable isotope probing of methanogenic archaea in the rice rhizosphere. Science 309(5737):1088-1090

87. Luláková P, Perez-Mon C, Šantrůčková H, Ruethi J, Frey B (2019) High-alpine permafrost and active-layer soil microbiomes differ in their response to elevated temperatures. Front Microbiol 10:668

88. Ma B, Wang Y, Ye S, Liu S, Stirling E, Gilbert JA, Xu J (2020) Earth microbial co-occurrence network reveals interconnection pattern across microbiomes. Microbiome 8:1-12

89. Mahdhi M, Tounekti T, Khemira H (2018) Invasive character of Prosopis juliflora facilitated by its allelopathy and a wide mutualistic interaction with soil microorganisms. J Biol Sci 18(3):115-123

90. Margulies M, Egholm M, Altman WE, Attiya S, Bader JS, Bemben LA, Rothberg JM (2005) Genome sequencing in microfabricated high-density picolitre reactors. Nature 437(7057):376-380

91. Martiny AC (2019) High proportions of bacteria are culturable across major biomes. ISME J 13(8):2125-2128

92. Meena RS, Kumar S, Datta R, Lal R, Vijayakumar V, Brtnicky M, Jangir CK (2020) Impact of agrochemicals on soil microbiota and management: A review. Land 9(2):34

93. Melguizo-Ruiz N, Jiménez-Navarro G, De Mas E, Pato J, Scheu S, Austin AT, Moya-Laraño J (2020) Field exclusion of large soil predators impacts lower trophic levels and decreases leaf-litter decomposition in dry forests. J Anim Ecol 89(2):334-346

94. Meliani A, Bensoltane A, Mederbel K (2012) Microbial diversity and abundance in soil: related to plant and soil type. American Journal of Plant Nutrition and Fertilization Technology 2(1):10-18

95. Mishra, A., \& Singh, D. [2020]. Role of Soil Fauna: En Route to Ecosystem Services and Its Effect on Soil Health. In Phytobiomes: Current Insights and Future Vistas [pp. 105-126]. Springer, Singapore.

96. Morrissey EM, Mau RL, Hayer M, Liu X-JA, Schwartz E, Dijkstra P, Hofmockel K (2019) Evolutionary history constrains microbial traits across environmental variation. Nature Ecology \& Evolution 3(7):1064-1069

97. Müller AK, Westergaard K, Christensen S, Sørensen SJ (2001) The effect of long-term mercury pollution on the soil microbial community. FEMS Microbiol Ecol 36(1):11-19

98. Murphy BW (2015) Impact of soil organic matter on soil properties - a review with emphasis on Australian soils. Soil Research 53(6):605-635
99. Nakamoto T, Yamagishi J, Miura F (2006) Effect of reduced tillage on weeds and soil organisms in winter wheat and summer maize cropping on Humic Andosols in Central Japan. Soil and Tillage Research 85(1-2):94-106

100. Naylor D, Sadler N, Bhattacharjee A, Graham EB, Anderton CR, McClure R, Jansson JK (2020) Soil microbiomes under climate change and implications for carbon cycling. Annu Rev Environ Resour 45(1):29-59

101. Nielsen UN, Ayres E, Wall DH, Bardgett RD (2011) Soil biodiversity and carbon cycling: a review and synthesis of studies examining diversity-function relationships. Eur J Soil Sci 62(1):105-116

102. Nielsen UN, Wall DH, Six J (2015) Soil biodiversity and the environment. Annu Rev Environ Resour 40:63-90

103. Niewiadomska, A. [2004]. Effect of Carbendazim, Imazetapir and Thiram on Nitrogenase Activity, the Number of Microorganisms in Soil and Yield of Red Clover [Trifolium pratense L.]. Polish Journal of Environmental Studies, 13[4].

104. Nikrad, M. P., Kerkhof, L. J., \& Häggblom, M. M. [2016]. The subzero microbiome: microbial activity in frozen and thawing soils. FEMS microbiology ecology, 92[6], fiw081.

105. Ochoa-Hueso R, Collins SL, Delgado-Baquerizo M, Hamonts K, Pockman WT, Sinsabaugh RL, Power SA (2018) Drought consistently alters the composition of soil fungal and bacterial communities in grasslands from two continents. Glob Change Biol 24(7):2818-2827

106. Offre, P., Spang, A., \& Schleper, C. [2013]. Archaea in biogeochemical cycles. Annual Review of Microbiology, 67.

107. Oliverio, A. M., Geisen, S., Delgado-Baquerizo, M., Maestre, F. T., Turner, B. L., \& Fierer, N. [2020]. The global-scale distributions of soil protists and their contributions to belowground systems. Science advances, 6[4], eaax8787.

108. Orgiazzi, A., Bardgett, R. D., \& Barrios, E. [2016]. Global soil biodiversity atlas: European Commission.

109. Pajares S, Bohannan BJ (2016) Ecology of nitrogen fixing, nitrifying, and denitrifying microorganisms in tropical forest soils. Front Microbiol 7:1045

110. Pampulha M, Oliveira A (2006) Impact of an herbicide combination of bromoxynil and prosulfuron on soil microorganisms. Curr Microbiol 53(3):238-243

111. Parihar M, Rakshit A, Meena VS, Gupta VK, Rana K, Choudhary M, Jatav HS (2020) The potential of arbuscular mycorrhizal fungi in C cycling: a review. Arch Microbiol 202:1581-1596

112. Pepe-Ranney C, Campbell AN, Koechli CN, Berthrong S, Buckley DH (2016) Unearthing the ecology of soil microorganisms using a high resolution DNA-SIP approach to explore cellulose and xylose metabolism in soil. Front Microbiol 7:703

113. Pérez-Izquierdo L, Zabal-Aguirre M, González-Martínez SC, Buée M, Verdú M, Rincón A, Goberna M (2019) Plant intraspecific variation modulates nutrient cycling through its below ground rhizospheric microbiome. J Ecol 107(4):1594-1605

114. Prasad, S., Malav, L. C., Choudhary, J., Kannojiya, S., Kundu, M., Kumar, S., \& Yadav, A. N. [2021]. Soil microbiomes for healthy nutrient recycling. In Current Trends in Microbial Biotechnology for Sustainable Agriculture [pp. 1-21]. Springer, Singapore.

115. Prosser JI (2015) Dispersing misconceptions and identifying opportunities for the use of'omics' in soil microbial ecology. Nat Rev Microbiol 13(7):439-446

116. Pulleman M, Six J, Van Breemen N, Jongmans A (2005) Soil organic matter distribution and microaggregate characteristics as affected by agricultural management and earthworm activity. Eur J Soil Sci 56(4):453-467

117. Pylro VS, Roesch LFW, Ortega JM, do Amaral, A. M., Tótola, M. R., Hirsch, P. R., Rosa, C. A. (2014) Brazilian microbiome project: revealing the unexplored microbial diversity—challenges and prospects. Microb Ecol 67(2):237-241 
118. Rai, P. K., \& Singh, J. S. [2020]. Invasive alien plant species: Their impact on environment, ecosystem services and human health. Ecological indicators, 111, 106020.

119. Ramirez KS, Leff JW, Barberán A, Bates ST, Betley J, Crowther TW, Fierer N (2014) Biogeographic patterns in below-ground diversity in New York City's Central Park are similar to those observed globally. Proceedings of the royal society B: biological sciences 281(1795):20141988

120. Ricciardi A, Blackburn TM, Carlton JT, Dick JT, Hulme PE, Iacarella JC, MacIsaac HJ (2017) Invasion science: a horizon scan of emerging challenges and opportunities. Trends Ecol Evol 32(6):464-474

121. Richardson AE, Simpson RJ (2011) Soil microorganisms mediating phosphorus availability update on microbial phosphorus. Plant Physiol 156(3):989-996

122. Rinot O, Levy GJ, Steinberger Y, Svoray T, Eshel G (2019) Soil health assessment: A critical review of current methodologies and a proposed new approach. Sci Total Environ 648:1484-1491

123. Rocca JD, Simonin M, Blaszczak JR, Ernakovich JG, Gibbons SM, Midani FS, Washburne AD (2019) The microbiome stress project: toward a global meta-analysis of environmental stressors and their effects on microbial communities. Front Microbiol 9:3272

124. Sahner, J., Budi, S. W., Barus, H., Edy, N., Meyer, M., Corre, M. D., \& Polle, A. [2015]. Degradation of root community traits as indicator for transformation of tropical lowland rain forests into oil palm and rubber plantations. PloS one, 10[9], e0138077.

125. Schneider F, Don A, Hennings I, Schmittmann O, Seidel SJ (2017) The effect of deep tillage on crop yield-What do we really know? Soil and Tillage Research 174:193-204

126. Schnoes, A. M., Brown, S. D., Dodevski, I., \& Babbitt, P. C. [2009]. Annotation error in public databases: misannotation of molecular function in enzyme superfamilies. PLoS computational biology, 5[12].

127. Schulz G, Schneider D, Brinkmann N, Edy N, Daniel R, Polle A, Krashevska V (2019) Changes in trophic groups of protists with conversion of rainforest into rubber and oil palm plantations. Front Microbiol 10:240

128. Sessitsch A, Weilharter A, Gerzabek MH, Kirchmann H, Kandeler E (2001) Microbial population structures in soil particle size fractions of a long-term fertilizer field experiment. Appl Environ Microbiol 67(9):4215-4224

129. Sheik CS, Beasley WH, Elshahed MS, Zhou X, Luo Y, Krumholz LR (2011) Effect of warming and drought on grassland microbial communities. ISME J 5(10):1692-1700

130. Shepherd MA, Harrison R, Webb J (2002) Managing soil organic matter-implications for soil structure on organic farms. Soil Use Manag 18:284-292

131. Siles JA, Margesin R (2016) Abundance and diversity of bacterial, archaeal, and fungal communities along an altitudinal gradient in alpine forest soils: what are the driving factors? Microb Ecol 72(1):207-220

132. Simpson AJ, Simpson MJ, Smith E, Kelleher BP (2007) Microbially derived inputs to soil organic matter: are current estimates too low? Environ Sci Technol 41(23):8070-8076

133. Singh D, Slik JF, Jeon Y-S, Tomlinson KW, Yang X, Wang J, Adams JM (2019) Tropical forest conversion to rubber plantation affects soil micro-\& mesofaunal community \& diversity. Sci Rep 9(1):1-13

134. Six J, Bossuyt H, Degryze S, Denef K (2004) A history of research on the link between [micro] aggregates, soil biota, and soil organic matter dynamics. Soil and Tillage Research 79(1):7-31
135. Six J, Feller C, Denef K, Ogle S, de Moraes Sa JC, Albrecht A (2002) Soil organic matter, biota and aggregation in temperate and tropical soils-Effects of no-tillage. Agronomie 22(7-8):755-775

136. Snyder BA, Boots B, Hendrix PF (2009) Competition between invasive earthworms [Amynthas corticis, Megascolecidae] and native North American millipedes [Pseudopolydesmus erasus, Polydesmidae]: effects on carbon cycling and soil structure. Soil Biol Biochem 41(7):1442-1449

137. Song, H., Singh, D., Tomlinson, K. W., Yang, X., Ogwu, M. C., Slik, J. F., \& Adams, J. M. [2019]. Tropical forest conversion to rubber plantation in southwest China results in lower fungal beta diversity and reduced network complexity. FEMS microbiology ecology, 95[7], fiz092.

138. Stein LY, Klotz MG (2016) The nitrogen cycle. Curr Biol 26(3):R94-R98

139. Thakur, M. P., \& Geisen, S. [2019]. Trophic regulations of the soil microbiome. Trends in microbiology.

140. Thompson LR, Sanders JG, McDonald D, Amir A, Ladau J, Locey KJ, Ackermann G (2017) A communal catalogue reveals Earth's multiscale microbial diversity. Nature 551(7681):457-463

141. Tsiafouli MA, Thébault E, Sgardelis SP, De Ruiter PC, Van Der Putten WH, Birkhofer K, Brady MV (2015) Intensive agriculture reduces soil biodiversity across Europe. Glob Change Biol 21(2):973-985

142. Van der Wal A, Geerts R, Korevaar H, Schoutenop Akkerhuis, G. J. Rutgers, M., \& Mulder, C. A (2009) Dissimilar response of plant and soil biota communities to long-term nutrient addition in grasslands. Biology and fertility of soil 45(6):663-667

143. Videmšek U, Hagn A, Suhadolc M, Radl V, Knicker H, Schloter M, Vodnik D (2009) Abundance and diversity of CO 2-fixing bacteria in grassland soils close to natural carbon dioxide springs. Microb Ecol 58(1):1-9

144. Waldron KJ, Rutherford JC, Ford D, Robinson NJ (2009) Metalloproteins and metal sensing. Nature 460(7257):823-830

145. Wang, C., Wang, X. U., Pei, G., Xia, Z., Peng, B. O., Sun, L., ... \& Bai, E. [2020]. Stabilization of microbial residues in soil organic matter after two years of decomposition. Soil Biology and Biochemistry, 141, 107687.

146. Wei H, Liu W, Zhang J, Qin Z (2017) Effects of simulated acid rain on soil fauna community composition and their ecological niches. Environ Pollut 220:460-468

147. Wiesmeier M, Urbanski L, Hobley E, Lang B, von Lützow M, Marin-Spiotta E, Kögel-Knabner I (2019) Soil organic carbon storage as a key function of soils-A review of drivers and indicators at various scales. Geoderma 333:149-162

148. Wolters V (2000) Invertebrate control of soil organic matter stability. Biol Fertil Soils 31(1):1-19

149. Yadav, A. N. [2017]. Agriculturally important microbiomes: biodiversity and multifarious PGP attributes for amelioration of diverse abiotic stresses in crops for sustainable agriculture. Biomed J Sci Tech Res, 1[4], 861-864.arch, 53[6], 605-635.

150. Yang G, Wagg C, Veresoglou SD, Hempel S, Rillig MC (2018) How soil biota drive ecosystem stability. Trends Plant Sci 23(12):1057-1067

151. Yang, J., Kang, Y., Sakurai, K., \& Ohnishi, K. [2017]. Fixation of carbon dioxide by chemoautotrophic bacteria in grassland soil under dark conditions. Acta Agriculturae Scandinavica, Section B-Soil \& Plant Science, 67[4], 362-371.

152. Ying T, Wei C (2019) Soil microbiomes-a promising strategy for contaminated soil remediation: a review. Pedosphere 29(3):283-297

153. Young I, Ritz K (2000) Tillage, habitat space and function of soil microbes. Soil and Tillage Research 53(3-4):201-213 
154. Yuan H, Ge T, Zou S, Wu X, Liu S, Zhou P, Wu J (2013) Effect of land use on the abundance and diversity of autotrophic bacteria as measured by ribulose-1, 5-biphosphate carboxylase/oxygenase [RubisCO] large subunit gene abundance in soils. Biol Fertil Soils 49(5):609-616

155. Zhang, H.-Y., Goncalves, P., Copeland, E., Qi, S.-S., Dai, Z.-C., Li, G.-L., Thomas, T. [2020]. Invasion by the weed Conyza canadensis alters soil nutrient supply and shifts microbiota structure. Soil Biology and Biochemistry, 143, 107739.
156. Zhang S, Li Q, Lü Y, Zhang X, Liang W (2013) Contributions of soil biota to $\mathrm{C}$ sequestration varied with aggregate fractions under different tillage systems. Soil Biol Biochem 62:147-156

157. Zhou J, Xia B, Treves DS, Wu LY, Marsh TL, O’Neill RV, Tiedje JM (2002) Spatial and resource factors influencing high microbial diversity in soil. Appl Environ Microbiol 68(1):326-334 